\title{
Editorial: In the Shadow of Covid-19
}

The performing and publication of public theology continues to take place in this time of a global pandemic. On occasions this context provokes an explicit act of a public theology; at other times the virus lies in the background but in a way which cannot be disregarded. It is 'there'. This collection of articles intersect with the Covid-19 crisis in different ways: sometimes the 'terrible times' looms large; sometimes it is not mentioned but it is not difficult to see where potential lines of connection are.

One of the features of 2020 was the cancellation of face-to-face conferences. So much happened on-line and was organized in the midst of uncertainty as to how best to proceed. Jason Sexton considers the implications of Covid-19 from the perspective of representative academic institutional life - in this instance the western regional conference of the American Academy of Religion. In the midst of competing demands in a time of crisis - teaching, examinations, administration and research - what ought to be the role of theological and religious scholars? Do the necessary and ever-pressing demands of the institution absorb all the available energy - or, do the various disciplines on show at a regional conference have the capacity to draw upon the resources of their faith traditions 'to interpret the phenomenon' - the 'terrible'? Sexton notes that most religious traditions have a long history of responding to plagues and possess a wisdom and 'riches' that can be helpful in times of 'mixed messages' (what he calls 'an inebriating cocktail of confusing information'). The case is made for theological and religious institutions to 'cultivate an ecology of ethical responsibility and care'.

Sexton is writing self-consciously out of California. Alexander Belyaev and Yulia Matushanskaya are responding to the pandemic from their particular context in Russia. They delve into Russian religious philosophy as well as an interrupted exposure to western critical scholarship to examine the public role of apocalyptic literature. The public sphere in this instance is constituted by a sequence of active social media conversations responding to the disturbing health statistics to do with Covid-19 in the post-Soviet context. What is especially striking to a public theology in the west is the level of apocalyptic thinking being expressed by what may be termed 'the social influencers' and the consequent need to clarify the nature and function of that line of thought. Belyaev and Matushanskaya demonstrate a familiarity with contemporary 
biblical and theological scholarship to do with 'the apocalyptic turn' in these disciplines as they reveal the argument for Covid-19 to be seen in the light of a 'rehearsal of the apocalypse'. It is a distinctive context: this rehearsal allows for the possibility of judgement on existing all too human social systems as well a rehearsal for the practice of compassion and kindness.

The road to recovery out of Covid-19 is complex. Future well-being is not simply a matter of the global distributions of vaccines. In some countries like Australia the pandemic has led to skyrocketing property prices and the increasing wealth of the rich while others have been left jobless or in positions of economic vulnerability. Writing out of Indonesia - and, thus, from a distinctly Asian perspective - Yahya Wijaya notes the role of small business (which is often family-based) in response to economic crises. It is likely to do so again with regards to the setbacks brought about by Covid-19. Wijaya's thesis represents a break away from the conventional theological discourse on economic matters which is inclined to focus upon the disparity between the poor and the powerful. Wijaya argues the case for small business occupying an 'inbetween' space between the two. In the very first volume of this journal John de Gruchy identified a preference for the poor as being a marker of good praxis for a public theology. In this article Wijaya exchanges the small for the poor and considers a number of biblical narratives around which a public theology for small business might be developed.

One of the unexpected consequences of Covid-19 has been a reduction in emissions from air travel and the rather surprising impact on wild life in urban areas. This ongoing season of the pandemic has coincided with the launch of the United Nations' Decade for Ecosystem Restoration. Writers for the anthology edited by Alexander Hampton on Pandemic, Ecology and Theology (Abingdon and New York: Routledge, 2021) were quick to realize what was obviously a health emergency was so much more than that: it raises profound questions for the economic and ecological systems and structures in and through which humankind lives. Climate health scientists are very aware of the links that can be made between pandemics, climate change and shifts in biodiversity.

Sungho Choi and Ji Young Jung were effectively writing in the midst of the presidency of Donald Trump. Their interest lies in the politics of climate change and how the Christian faith can be co-opted into a line of reasoning that is at odds with the majority of climate and Earth System scientists. The burden of their research is on the claims made by the conservative evangelical constituency in the United States which has tended to vote Republican in the Trump-era. Of particular interest for Choi and Jung is the Cornwall Alliance which takes issue with an environmental advocacy that 'slows economic 
growth'. They examine the claims of the Alliance and suggest that movement of the Right harbours a dualistic worldview and seemingly favours a 'gnosticlike withdrawal'. Their preferred option is for this escalating superwicked problem to do with climate is a creative 'interaction between science as well as the humanities, between religion with politics.' It is hardly time for denial,

Colin Toffelmire, Nikayla Reize and Beth Stovell make only a passing reference to the 'unique needs raised by the Covid-19 outbreak'. They do so while discussing the practice of the Calgary Alliance for the Common Good: the work of this 'non-partisan and non-profit alliance of congregations, unions, school and community groups' is seen as an illustration of how a local expression of a public theology might seek to alleviate poverty and promote human flourishing. The connection between a public theology and flourishing is made through the work of Miroslav Volf and Matthew Croasmun. For their part Toffelmire, Reize and Stovell are intent on using themes from Scripture especially, but not only, the Sabbath and jubilee - to demonstrate a biblical concern for flourishing which necessarily involves the desire to alleviate poverty. It is set alongside a frank recognition of how complex a multidisciplinary approach to poverty alleviation is.

With reference to the theme of the small and the poverty Steven van den Heuvel offers an alternative to human development via the capabilities approach employed by Amartya Sen and Martha Nussbaum. Its emphasis on 'valuable functionings' (Sen) and Nussbaum's list of ten capabilities or capacities furnishes a different means of discerning how a society is flourishing. The turn is away from GDP as the index for levels of development. It is invites a thinking through again of what constitutes a 'good life'. Van den Heuvel is mindful of how a range of disciplines are engaging with the capabilities approach: he assumes that it is in the interest of a public theology (with its commitment in certain circles to notions of flourishing) to do so as well. That task certainly coheres with a public theology's interest in being interdisciplinary. The dilemma he discerns is one of a confusion of method. What van den Heuvel proposes is a revised method of correlation which looks back to Paul Tillich and is developed through recourse to Dietrich Bonhoeffer's Ethics and Sanctorum Communio.

The pressures brought to bear on age care facilities during the pandemic have been immense for residents, staff and management. It could hardly have been imagined that the level of concern for these facilities would ever have become a key public issue. Virginia Miller, Seumas Miller and Bruce Stevens do not deal with the Covid-19 related issues to do with these facilities: what they do is draw attention to a problem that may well have become compounded 
during the year that has passed. Their work is on elder sexual abuse: how are the rights and dignities of older citizens to be respected while in care - and especially if they are suffering from some form of cognitive decline? What rights do caregivers have if the rights that are legislated for the elderly conflict with their beliefs? These kind of questions lie at the intersection of human rights and government policy and the provision of care by a religious agency.

Clive Pearson | ORCID: 0000-0003-2557-7562

Editor-in-chief

Public and Contextual Theology Research Centre,

Charles Sturt University, Australia

cpearson@csu.edu.au 